\title{
EXISTENTIAL ISSUES OF COMMITTEE CONSTRUCTIONS. PART I
}

\author{
VI.D. Mazurov1, 2 ,vldmazurov@gmail.com, \\ E.Yu. Polyakova'2, ekaterina.y.polyakova@gmail.com \\ ${ }^{1}$ N.N. Krasovskii Institute of Mathematics and Mechanics of the Ural Branch \\ of the Russian Academy of Sciences, Ekaterinburg, Russian Federation, \\ ${ }^{2}$ Ural Federal University named after the first President of Russia B.N. Yeltsin, \\ Ekaterinburg, Russian Federation
}

\begin{abstract}
The term "existence" is important in philosophy, mathematics and logic. Various approaches to logic research of existential expressions are possible. The question of relation of terms to the objects designated by them is important. These problems were considered by Aristotle in the names theory developed by him. Scholastic ... of suppositions regard this problem as well. From the middle of the $19^{\text {th }}$ century these problems were studied by J. Mill, W. Jevons, F. Brentano, A. Meinong, E. Husserl. Mill made a significant statement: names only have a task of naming something but to express that this something exists the predicate "to exist" is needed. Nevertheless F. Frege, B. Russell and R. Carnap believed that the expression of the language should be considered as a name only when it designates a real existing object, then the predicate of existence is unnecessary.

We believe that everything that we can think about or see or feel exists, whatever it is, though it exists in different meanings and in different degrees. The kinds of existence need to be differentiated. There is a round square even as an idea. But there exists a bridge of ideas forming a concept of a round square, for example, as a dynamic structure transforming with the time in topology or as a set of figures, some of them being similar to a square while others - to a circle. There exists $x: x>0$, $x<0$ also as an idea, as a set of two maximum consistent subsystems of the system. There is a generalized existence, for example according to Chebyshev's idea (when all the predicates of the concept are diminished) and in the meaning of committee constructions when all consistent subsystems of predicates are considered. There is an infinite point - a nonintrinsic element in the plane.
\end{abstract}

Keywords: committee constructions, existence, discriminatory analysis, factors, inequalities.

\section{Introduction}

S.N. Chernikov and later I.N. Eremin proved a number of important theorems of existence of solutions of infinite inequality systems, initiating a significant trend in linear optimization. One of the authors of the article, V1.D. Mazurov, took part in some of these research works. The following topic has occurred naturally: existence of committee constructions for infinite inequality systems.

Committee of the system $F_{j}(x)>0(j \in M), x \in \mathrm{R}^{n}$, there is a $C$ sequence, majority of elements of $C$ sequence satisfy every system inequality.

The article provides new proofs of theorems in case of infinite systems.

This topic turned out in demand in economics and mathematical linguistics. For example, in a frequently occurring situation of inconsistent problems at the enterprises of Ekaterinburg and the region a mathematical approach to informality and inconsistency was required. It concerns scheduling at engineering enterprise, planning and metallurgical production management, application in medicine and ecology as well as in physicotechnical sciences.

Recently multi-layer neural network has been applied to find empirical regularities when modelling enterprises. By means of learning multi-layer neural networks we found empirical regularities for several indicators of performance at industrial enterprises. Precedent material is the data on performance at the enterprise in Sverdlovsk region, provided by the Regional Statistical Department. These algorithms were applied in prognostication of several indicators of enterprise performance. Application of the image recognition methods or the appropriate neural network methods enables to solve some pending problems of economical and statistical modeling, to improve mathematical model adequacy, to approximate them to the economic reality. Application of image recognition combined with regressive analysis entailed new model types: classification ones and piecewise linear ones. Detecting hidden relations in data 


\section{Краткие сообщения}

bases is the foundation of modeling tasks and knowledge processing including those for the object with hard formalized regularities. Specific calculations have shown that when widening the sets of properties characterizing the performance of the enterprises, a more precise prognostication occurs, the same effect occurs when increasing the interval in the course of which the data on enterprises are being registered.

The problem of comparing the enterprises can be understood either as a problem of ranking the enterprises or as that of choosing the most preferable object out of a certain set. Practice has shown that the methods based on the application of a priori preference of factors and on the search of the object responsible for maximum weighted sum of factors lead to biased results.

\section{Experience of multi-layer neural network application to find empirical regularities when modelling enterprises}

Let us consider the problem of choosing the best enterprise. Let us suppose that there is a set of $\mathrm{M}$ objects, the activity of which is aimed at some goal achievement. The functioning of every object is characterized by $n$ property values, thus exists reflection $f: M \rightarrow \mathrm{R}^{n}$. Therefore our point of departure is a state vector of economical object: $x=\left[x_{1}, \ldots, x_{n}\right]$. Quality index of economic object functioning: $f_{0}(x)$, $f_{1}(x), \ldots, f_{m}(x)$. These indices shall be within certain limits, some of them we make either minimal or maximal. The general statement can be inconsistent and it can be necessary to overcome the inconsistency and state the problem in the correct form consistent with the economic point. We regulate the objects in terms of a certain criterion function but as a rule the criterion is ill-defined, diffuse and probably inconsistent.

We are considering the problem of empirical regularity modeling with little experimental and observational data. Mathematical model can represent a regression equation or a diagnostic rule or prediction rule. Recognition methods are more effective with a small sample. The impact of factor control is taken into account by means of factor score variations when they are substituted in a regularity equation or in decision diagnostic and prediction rule. Moreover we apply essential property selection and generation of useful properties (secondary parameters). This mathematical apparatus is needed to predict and diagnose the state of economical objects.

We are considering a neural network in terms of committee construction theory as a collective of neurons (individuals) and a neural network is a mechanism of coordinating neural work in committee decisions, this is a means of coordinating individual opinions when collective opinion is a correct reaction to the input, i.e. a required empirical relation.

Therefore now we are going to consider committee constructions application in the problems of choice and diagnostics. The idea is to search for a collective of decisive rules instead of the decisive one, the collective makes a collective decision under the procedure processing individual decisions of committee members. Choice and diagnostics models as a rule entail inconsistent inequality systems where the generalization of the notion of decision should be sought for instead of decisions. A collective decision is such a generalization.

For example an inequality system committee is such a set of elements where most of the elements of this set satisfy every inequality. Committee constructions represent a certain class of generalization of the concept of decisions for the problems either consistent or inconsistent ones. This is a class of discrete approximations for inconsistent problems, they can also be correlated with diffuse decisions.

\section{Committees of infinite systems of linear homogeneous inequalities over $R^{2}$ space}

The section is devoted to the question of existence of committee of homogeneous strict linear inequality system

$$
\left(c_{\alpha}, x\right)>0 \quad(\alpha \in M),
$$

where $x, c_{\alpha} \in \mathrm{R}^{2}, M$-infinite set of indices.

Theorem 2.1. The following conditions are necessary and sufficient for (2.1) system committee to exist:

1. Among vectors $c_{\alpha}$ there exist no null or opposite ones;

2. If $c,-c \in \overline{\left\{c_{\alpha} /\left\|c_{\alpha}\right\|\right\}}$, when $\varepsilon>0$ is sufficiently small, $\left(c_{\alpha}, x\right)>0$,

$\alpha \in M(c,-c, \varepsilon)$ subsystem is consistent.

Proof. Sufficiency will follow from theorem 2.2. Let us show the necessity: that of the first condition is evident, that of the second one will be proved by contradiction. Suppose there exists $K=\left\{h_{1}, \ldots, h_{q}\right\}$, 
system committee, and $c_{0}$, a point for which condition 2 is violated. Let us consider a line $H=\{x:(h, x)=0\}$ where $\left(h, c_{0}\right)>0$. Let us define two sets $A$ and $B$ in the following way:

$A=\left\{c /\|c\| \in \mathrm{R}^{2}: c \in\left\{c_{\alpha}\right\} \&(h, c) \geq 0\right\}$.

$B=\left\{c /\|c\| \in \mathrm{R}^{2}:-c \in\left\{c_{\alpha}\right\} \&(h,-c)<0\right\}$.

Let us give $H$ a positive direction. Then any point $c \in A \cup B$ will be definitely characterized by $\varphi \in[0, \pi]$ angle between radius-vector of the point and the chosen direction. By assumption $K$ is the committee of system

$$
\begin{aligned}
& (a, x)>0, a \in A, \\
& (b, x)<0, b \in B,
\end{aligned}
$$

besides, $c_{0} \in \bar{A} \cap \bar{B}$ and in no $\varepsilon$-neighborhood of $c_{0}$ point the system will become consistent. 3 cases are possible for $c_{0}$.

Case 1. $c_{0} \in A$. Since $A \cap B=\varnothing$, there exists such a sequence $b_{n} \in B$ that $b_{n} \rightarrow c_{0}$. Therefore $\varphi_{b n} \rightarrow \varphi_{c 0}$. Let us consider the points of $h$ committee that relate $c_{0}$ to $A$ class, i.e. $\left(h, c_{0}\right)>0$. These points are dominating in number. But in this case the same committee members will relate to $A$ class all the points lying in a certain $\varepsilon$-neighborhood of $c_{0}$ point. Since $b_{n} \rightarrow c_{0}$, then in any $\varepsilon$-neighborhood of $c_{0}$ there are points from $B$. Thus we get an inconsistency that $K$ is a separating committee.

Case 2. $c_{0} \in B$ is considered similarly.

Case 3. $c_{0}$ is a limit point for both sets. System inconsistency for any $\varepsilon$ means that there will be found 2 sequences $a_{n} \rightarrow c_{0}, b_{n} \rightarrow c_{0}$, the members of which are lying on the same side of $c_{0}$ vector, i.e.

$\forall n \varphi_{a n}<\varphi_{c 0}, \varphi_{b n}<\varphi_{c 0}$, or $\varphi_{a n}>\varphi_{c 0}, \varphi_{b n}>\varphi_{c 0}$.

Let, for example, there be $\varphi_{a n}<\varphi_{c 0}, \varphi_{b n}<\varphi_{c 0}$. Let us consider such $\varphi<\varphi_{c 0}$ that for any $h$ vector of $K$ committee the polar angle of cross point of $(h, x)=0$ line with unit semicircumference, where $c_{0}$ is lying, does not fall into $\left(\varphi, \varphi c_{0}\right)$ interval. Such $\varphi$ exists since the committee has a finite number of members. But in this case our committee will relate all the points, the angles of which are lying within $\left(\varphi, \varphi_{c 0)}\right.$ interval, to one class. This is an inconsistency, the theorem is proved.

Theorem 2.2. Let system (1) satisfies the conditions

1. Among $c_{0}$ vectors there exist no null or opposite ones.

2. If $c,-c \in \overline{\left\{c_{\alpha} /\left\|c_{\alpha}\right\|\right\}}$, when $\varepsilon>0$ is sufficiently small, $\left(c_{\alpha}, x\right)>0, \alpha \in M(c,-c, \varepsilon)$ subsystem is consistent.

Thus the number of all $\mu$-subsystems of the system is odd: $q=2 k+1$. For any $\beta \in M$ the number of the $\mu$-subsystems, the solution sets of which are in half-plane of $\left(c_{\beta}, x\right)>0$ inequality solutions, equals $k+1$.

Proof. Let us consider a general line $D=\{x:(d, x)=0\}$. Let us define two sets $A$ and $B$ :

$A=\left\{c /\|c\| \in \mathrm{R}^{2}: c \in\left\{c_{\alpha}\right\} \&(h, c) \geq 0\right\}$.

$B=\left\{c /\|c\| \in \mathrm{R}^{2}:-c \in\left\{c_{\alpha}\right\} \&(h,-c)<0\right\}$.

Let us give $D$ a positive direction. Let us order $A \cup B$ set by the increase of $\varphi \in[0, \pi]$ angle between radius-vector of the points and the positive direction of $D$. According to the condition the system is consistent in a certain $\varepsilon$-neighborhood of any $c \in \bar{A} \cap \bar{B}$. Then it is easy to see that for $c$ point (if $(c, d) \neq 0)$ only one situation is possible: in a sufficiently small c neighborhood the points of $A$ and $B$ sets are lying on semicircumference on the opposite sides of $c$, i.e.

$\exists \varepsilon>0: \forall a \in A, b \in B:\left|\varphi_{a}-\varphi_{c}\right|<\varepsilon,\left|\varphi_{b}-\varphi_{c}\right|<\varepsilon \Rightarrow \varphi_{a}<\varphi_{c}<\varphi_{b}$,

or

$\exists \varepsilon>0: \forall a \in A, b \in B:\left|\varphi_{a}-\varphi_{c}\right|<\varepsilon,\left|\varphi_{b}-\varphi_{c}\right|<\varepsilon \Rightarrow \varphi_{b}<\varphi_{c}<\varphi_{a}$.

Let us demonstrate that the number of $c \in \bar{A} \cap \bar{B}$ points can only be finite. Indeed, otherwise there can be found such $c_{n} \in \bar{A} \cap \bar{B}$ sequence that $c_{n} \rightarrow c_{0} \in \bar{A} \cap \bar{B}$. We will assume that, for example, $\varphi_{c n}<\varphi_{c 0}$ (the case of $\varphi_{c n}>\varphi_{c 0}$ is considered similarly). Then $\forall \varepsilon>0 \exists a \in A, b \in B:\left|\varphi_{a}-\varphi_{c 0}\right|<\varepsilon$, $\left|\varphi_{b}-\varphi_{c 0}\right|<\varepsilon \& \varphi_{a}<\varphi_{c 0}, \varphi_{b}<\varphi_{c 0}$.

Inconsistency. Let us put "+" sign in our ordered set $\bar{A} \cap \bar{B}$ to the points from $A$ and to the points from $B$ - "-“ sign. Due to number finiteness of c $\in \bar{A} \cap \bar{B}$ points, the number of sign change in the sequence will also be finite. It should be noticed that $h$ or $-h:(d, h) \neq 0$ vector will be the solution of a certain $\mu$-subsystem only in case of sign change when $(h, x)=0$ line passes through the cross point with unit semicircumference. But in this case as well as in the case with finite subsystem it is easy to see 


\section{Краткие сообщения}

that the number of all $\mu$-subsystems equals the number of sign change if the sequence starts with one sign and ends in another one, and otherwise is greater by $1($ due to $(d, x)=0)$ line itself. The theorem is proved.

The theorem proved represents a generalization of the relevant assertion for the finite system and states the so-called duality property for the systems of homogeneous linear inequalities over $\mathrm{R}^{2}$ space. It states that $\mu$-subsystems solutions, when one of the solutions is taken per every subsystem, represent a committee with the committee obtained in this way being minimal according to the number of members.

\section{Committees of systems of linear homogeneous inequalities in general}

This part considers the questions of committee solvability of the system of linear homogeneous equations.

$\left(c_{\alpha}, x\right)>0 \quad(\alpha \in M)$,

where $\left(x, c_{\alpha}\right) \in \mathrm{R}^{\mathrm{n}}, M$ - infinite set of indices. The following theorem specifies several necessary conditions of committee.

Theorem 3.1. The following conditions have to be fulfilled for $\left(c_{\alpha}, x\right)>0(\alpha \in M)$ system committee to exist:

1) among $c_{\alpha}$ vectors there exist no null or opposite ones;

2) If $c,-c \in \overline{\left\{c_{\alpha} /\left\|c_{\alpha}\right\|\right\}}$, then $c,-c \notin\left\{c_{\alpha} /\left\|c_{\alpha}\right\|\right\}$.

Proof. Let us prove necessity of the second condition by contradiction. Suppose there exist a certain $c$ vector such that $c,-c \in \overline{\left\{c_{\alpha} /\left\|c_{\alpha}\right\|\right\}}$ and $-c \in\left\{c_{\alpha} /\left\|c_{\alpha}\right\|\right\}$ is satisfied. Then there exist a sequence $c_{n} \in\left\{c_{\alpha} /\left\|c_{\alpha}\right\|\right\}, c_{n} \rightarrow-c$. Suppose $K=\left\{x_{1}, x_{2}, \ldots, x_{k}\right\}$ is an element of the committee system. Let us consider $y \in K_{1} \subseteq K$ points where $(y, c)>0$. Then according to the committee definition $\left|K_{1}\right|>|K| / 2$. Since there is a finite number of points, such $\varepsilon$-neighborhood of $c$ point is found that

$\forall d \in R^{n}, \forall y \in K_{1}:\|d-c\|<\varepsilon \Rightarrow(d, y)>0$.

Therefore $\forall d \in \mathrm{R}^{n}, \forall y \in K_{1}:\|d+c\|<\varepsilon \Rightarrow(d, y)<0$.

Starting from a certain number the points of $c_{n}$ sequence occur in this $\varepsilon$-neighborhood, thus for them $\left(c_{n}, y\right)<0 \forall y \in K_{1}$. It contradicts the fact that $K$ is the system committee. The theorem is proved.

We should notice that for committee solvability of the system of linear homogeneous inequalities over $\mathrm{R}^{2}$ space the condition of finiteness of the number of maximum consistent systems was necessary. The following example demonstrates that in the spaces of greater dimension the condition is not necessary, i.e. there exist the systems of homogeneous linear inequalities with an infinite number of $\mu$-subsystems and they are committee solvable.

Example 3.1. Let us consider linear inequality system over $\mathrm{R}^{3}$.

$0 x_{1}-(1 / n) x_{2}+x_{3}>0$

$2 x_{1}+(1 / n) x_{2}+x_{3}>0$,

$(1 / n) x_{1}+\left(1 / n^{2}\right) x_{2}+x_{3}<0, n=1,2, \ldots$

For this system there exists a committee consisting of three members:

$y^{1}=[0,-1,0], y^{2}=[0,1,2], y^{3}=[1,0,-1,5]$. Let us demonstrate that the system has infinite sets of maximum consistent subsystems. Since all the points of the system are lying in one plane it will be sufficient to demonstrate that there exist infinitely many $\mu$-subsystems in the problem of set separation $A=\{[0,-1 / n]\} \cup\{[2,1 / n]\}$ and $B=\left\{\left[1 / n, 1 / n^{2}\right]\right\}$ by affine functional. Let us consider a line $Y_{\lambda}=\left\{x \in \mathrm{R}^{2}: x_{1}-\lambda x_{2}=0\right\}$ at sufficiently high $\lambda$. Let us take such two points as $a_{m} \in\{[2,1 / n]\}$, $b_{k} \in B$ that $a_{m}$ is the closest to the line point lying strictly lower $Y_{\lambda}, b_{k}$ is the closest point above the line. Then $Y_{\lambda}$ is a separating function of subsystem $\{[0,-1 / n]\}, n \in N ;\{[2,1 / n]\} n \geq m ;\left\{\left[1 / n, 1 / n^{2}\right]\right\} n \leq k$.

Let us consider all consistent subsystems containing this one. There is obviously a finite number of them, thus among them there exist maximum consistent ones. Increasing $\lambda$ parameter (of course, in certain increments) we will obtain new $\mu$-subsystems. Since when increasing $\lambda m$ number is increasing, and at $\lambda \rightarrow \infty$ we will find infinitely many different maximum consistent subsystems.

It occurs that condition 2) of theorem 2.1. in spaces with dimension over 2 is not necessary for the committee of the systems of homogeneous linear inequalities to exist. This statement is justified by the following example. 
Example 3.2. The system is given:

$(1 / n) x_{1}+0 x_{2}+2 x_{3}>0$,

$0 x_{1}+(1 / n) x_{2}+2 x_{3}>0$,

$-(1 / n) x_{1}-(1 / n) x_{2}+2 x_{3}>0$,

$-(1 / n) x_{1}+0 x_{2}+(2-1 / n) x_{3}<0, n=1,2, \ldots$

System $\left(c_{\alpha}, x\right)>0$ has a $c$ point such that $c,-c \in \overline{\left\{c_{\alpha} /\left\|c_{\alpha}\right\|\right\}}: c=[0,0,1]$ and at any $\varepsilon>0$ subsystem $\left(c_{\alpha}, x\right)>0, \alpha \in M(c,-c, \varepsilon)$ is inconsistent. Indeed, if it were consistent then for any of its solutions $y$ the equation $(y, c)=0$ would be satisfied, i.e. $y$ vector would lie in plane $x_{3}=0$ but system $(1 / n) x_{1}+0 x_{2}>0,0 x_{1}+(1 / n) x_{2}>0,-(1 / n) x_{1}-(1 / n) x_{2}>0$, is obviously inconsistent. On the contrary the initial system is committee solvable. As a committee the set of three members can be taken, for example, $x^{1}=[1,1,0], x^{2}=[1,-1.5,0], x^{3}=[-1.5,1,0]$.

\section{Conclusions}

1. Committee constructions theory (including the conditions of their existence) and their practical application have demonstrated high efficiency of this method.

2. M.Yu. Khachai and A. Rybin obtained only substantiated assessments of the complexity of the method.

3. Therefore the method is ready for the further application in technoeconomic, medical and biological problems.

4. The problems of postoptimal analysis of solving practical problems have been clarified.

\section{References}

1. Astaf'yev N.N. Lineynye neravenstva $i$ vypuklost' [Linear Inequalities and Camber]. Moscow. Nauka Publ., 1982. 153 p.

2. Kolmogorov A.N., Fomin S.V. Elementy teorii funktsiy i funktsional'nogo analiza [Elements of the Theory of Functions and Functional Analysis]. Moscow, Nauka Publ., 1976. 543 p.

3. Eremin I.I., Mazurov V1.D. Nestatsionarnye protsessy matematicheskogo programmirovaniya [Non-Stationary Processes of Mathematical Programming]. Moscow, Nauka Publ., 1979. 288 p.

4. Mazurov V1.D. Metod komitetov v zadachakh optimizatsii i klassifikatsii [Metod of Committees in Problems of Optimization and Classification]. Moscow, Nauka Publ., 1990. 245 p.

5. Mazurov V1.D. Matematicheskie metody raspoznavaniya obrazov [Mathematical Methods of Recognition of Images]. Ekaterinburg, Ural Univ. Publ., 2010. 101 p.

6. Mazurov V1., Hachay M.Yu. [Committee Structures]. News of Ural State Univ., Mathematics and mechanics, 1999, iss. 2, no. 14, pp. 77-108. (in Russ.)

7. Khachay M.Yu. Committee Polyhedral Separability: Complexity and Polynomial Approximation. Machine Learning. Springer US, 2015, vol. 101, no. 1-3, pp. 231-251. DOI: 10.1007/s10994-015-5505-0

Received 10 June 2018 


\title{
ЭКЗИСТЕНЦИАЛЬНЫЕ ВОПРОСЫ КОМИТЕТНЫХ КОНСТРУКЦИЙ. ЧАСТЬ I
}

\author{
Вл.Д. Мазуров ${ }^{1,2}$, Е.Ю. Полякова \\ ${ }^{1}$ Институт математики и механики им. Н.Н. Красовского УрО РАН, \\ г. Екатеринбург, Россия, \\ ${ }^{2}$ Уральский фредеральный университет им. первого Президента России Б.Н. Ельцина, \\ г. Екатеринбург, Россия
}

\begin{abstract}
В философии, математике и логике важен термин «существование». Возможны различные подходы к логическому исследованию экзистенциальных высказываний. Важен вопрос об отношении терминов к обозначаемым ими объектам. Эти проблемы рассматривал ещё Аристотель в разработанной им теории имён. С середины XIX века эти проблемы изучали Дж. Милль, У. Джевонс, Ф. Брентано, А. Мейнонг, Э. Гуссерль. Милль высказал важное суждение: имена только имеют задачу назвать нечто, а чтобы выразить, что это нечто существует, необходим предикат «существовать». Однако Ф. Фреге, Б. Рассел и Р. Карнап считали, что выражение языка следует рассматривать как имя лишь в том случае, когда оно обозначает реально существующий объект, и тогда предикат существования излишен.

Авторы считают: существует всё, о чем мы можем подумать или что увидеть и почувствовать. Всё, что угодно. Только существует в разных смыслах, в разной степени. Надо просто различать виды существования. Существует круглый квадрат - хотя бы как идея. Но существует и мостик из идей, реально конструирующих понятие круглого квадрата. Например, как динамическая фигура, с течением времени трансформирующаяся - как в топологии. Или размыто - как набор фигур, одни из них больше похожи на квадрат, другие - на круг. Существует $x: x>0, x<0$. Тоже как идея. Как набор двух максимальных совместных подсистем этой системы. Есть обобщенное существование. Например, в чебышевском смысле (когда ослабляются все предикаты понятия) и в смысле комитетных конструкций - когда рассматриваются все непротиворечивые подсистемы предикатов. На плоскости существует бесконечно удаленная точка - несобственный элемент.

Ключевые слова: комитетные конструкиии, существование, дискриминантный анализ, факторы, неравенства.
\end{abstract}

\footnotetext{
Литература

1. Астафьев, Н.Н. Линейные неравенства и выпуклость / Н.Н. Астафьев-М.: Наука, 1982. $153 \mathrm{c}$.

2. Колмогоров, А.Н. Элементы теории функций и функционального анализа / А.Н. Колмогоров, С.В. Фомин. - М.: Наука, 1976. - 543 с.

3. Еремин, И.И. Нестационарные прочессы математического программирования / И.И. Еремин, Вл.Д. Мазуров - М.: Наука, 1979. - 288 с.

4. Мазуров, Вл.Д. Метод комитетов в задачах оптимизации и классификации / Вл.Д. Мазуров. - М.: Наука, 1990. - 245 с.

5. Мазуров, Вл.Д. Математические методы распознавания образов / Вл.Д. Мазуров. - Екатеринбург: Изд-во Урал. ун-та, 2010. - 101 с.

6. Мазуров, Вл.Д. Комитетные конструкиии / Вл.Д. Мазуров, М.Ю. Хачай // Изв. Урал. гос. ун-та. Математика и механика. - 1999. - Bып. 2, № 14. - C. 77-108.

7. Khachay, M.Yu. Committee polyhedral separability: complexity and polynomial approximation / M.Yu. Khachay // Machine Learning. Springer US. - 2015. - Vol. 101, no. 1-3. - P. 231-251. DOI: 10.1007/s10994-015-5505-0
} 
Мазуров Владимир Данилович, д-р физ.-мат. наук, ведущий научный сотрудник, Институт математики и механики им. Н.Н. Красовского УрО РАН; профессор, кафедра эконометрики и статистики Высшей школы экономики и менеджмента, Уральский федеральный университет им. первого Президента России Б.Н. Ельцина, г. Екатеринбург; vldmazurov@gmail.com.

Полякова Екатерина Юрьевна, старший преподаватель, кафедра издательского дела Уральского гуманитарного института, Уральский федеральный университет им. первого Президента России Б.Н. Ельцина, г. Екатеринбург; ekaterina.y.polyakova@gmail.com.

Поступила в редакцию 10 июня 2018 г.

\section{ОБРАЗЕЦ ЦИТИРОВАНИЯ}

Mazurov, V1.D. Existential Issues of Committee Constructions. Part I / Vl.D. Mazurov, E.Yu. Polyakova // Вестник ЮУрГУ. Серия «Компьютерные технологии, управление, радиоэлектроника». - 2018. - Т. 18, № 3. C. $165-171$. DOI: $10.14529 /$ ctcr180318

\section{FOR CITATION}

Mazurov V1.D., Polyakova E.Yu. Existential Issues of Committee Constructions. Part I. Bulletin of the South Ural State University. Ser. Computer Technologies, Automatic Control, Radio Electronics, 2018, vol. 18, no. 3, pp. 165-171. DOI: $10.14529 /$ ctcr180318 